\title{
Sources of value co-destruction: Uber customer perspectives
}

\section{Erose Sthapit and Peter Björk}

\author{
Erose Sthapit is based at \\ Department of Marketing, \\ Vaasan yliopisto \\ Kauppatieteellinen \\ tiedekunta, Vaasa, Finland. \\ Peter Björk is based at \\ Svenska handelshogskolan \\ Vasa Campus, Vaasa, \\ Finland.
}

\begin{abstract}
Purpose - This study aims to explore the antecedents that generate value co-destruction, the negative outcomes resulting from interactive value formation, in the sharing economy context, particularly taxi services. The focus of the study is on customers' Uber reviews that are written in English and posted online. Three keywords, "bad", "terrible" and "awful", were used to capture online narratives linked to customers' negative experiences with Uber. Out of the 758 online reviews, 75 negative reviews were analysed in this study.

Design/methodology/approach - A grounded theory approach was used for data analysis.

Findings - Two distinct themes resulted in value co-destruction: Uber drivers' bad behaviour and poor customer service. The managerial implications include that Uber clearly should invest more resources to minimise the negative experiences of its customers by clearly defining the taxi drivers' tasks and responsibilities. In addition, when customers report their dissatisfaction, they should be dealt with promptly and effectively through good customer service.

Research limitations/implications - First, the netnography study, by its nature, was restricted to those customers who shared their reviews online. The study did not consider those customers who have not posted their reviews online. Second, the focus of the study was on customer reviews that were written in English. Third, only three keywords ("bad", "terrible" and "awful") were used in the data selection process, limiting the number of review posts (75) that were analysed in this study. In addition, even if this study does not produce statistically generalizable findings, the findings are valuable in an analytical sense.

Practical implications - From a managerial perspective, Uber clearly should invest more in resources to minimise the negative experiences of its customers (both domestic customers and tourists) by clearly defining the taxi drivers' tasks and responsibilities. If the drivers' tasks are unclear, then customers cannot be served in an effective manner and with consistent service quality. The taxi drivers, regardless of their full-time or part-time work shifts, should ensure that quality services are offered to customers. Providing high-quality service might reduce the number of complaints and result in positive comments and compliments.
\end{abstract}

Originality/value - This study addresses the gap in previous literature by examining customers' negative experiences during the overall service encounter and antecedents of value co-destruction in the context of Uber. This study contributes to a better understanding of value co-destruction within the sharing economy.

Keywords Transportation, Value co-destruction, Sharing economy, Uber, Interactive value formation Paper type Research paper

\section{Introduction}

Studies on value co-creation have been increasingly applied in the field of tourism (Chathoth et al., 2016). Value co-creation refers to a resource integration process between the provider and the customer (Vargo and Lusch, 2008) and that all the actors involved in the process act to benefit from the interaction. The customer plays a crucial role in this process (Grönroos, 2012) and technology is being used to co-create enhanced experiences. In addition, information and communication technology (ICT) have drastically changed the nature of the tourism experience (Buhalis and Law, 2008; Pesonen, 2013) by empowering co-creation (Kirillova and Wang, 2016; Neuhofer et al., 2012) and extending 
the space in which experiences can be co-created (Neuhofer et al., 2012). In addition, these technologies add value to tourist experiences in a concrete manner by fostering co-creation (Neuhofer et al., 2015). In the same vein, co-creation opportunities at destinations are reliant on the exchange of touristic resources, facilitated by a plethora of technologies (Bustard et al., 2019).

However, there is growing evidence that consumers experience negative service encounters in which value is co-destroyed during this interactive value formation (IVF) process (Echeverri and Skålen, 2011; Sthapit and Björk, 2018). In the same vein, negative accounts of IVF, co-destruction of value (Echeverri and Skålen, 2011; Plé, 2017) as well as its antecedents (Prior and Marcos-Cuevas, 2016; Vafeas et al., 2016), remain largely unexplored in tourism research.

Value co-creation and co-destruction are two aspects of IVF that can exist simultaneously (Smith, 2013). In fact, Plé's (2017) study indicates that value co-creation and co-destruction can be regarded as two sides of the same coin. Value co-destruction refers to a failed interaction process that has a negative outcome. Value co-destruction can emerge, for example, when the actors involved in a relationship do not possess a certain resource (Smith, 2013), such as information (Vafeas et al., 2016), which is the focus of this study. The justification for this study is that studying value co-destruction will provide a more comprehensive picture of the phenomenon, which recent studies have called for (Plé, 2017; Prior and Marcos-Cuevas, 2016; Vafeas et al., 2016; Sthapit and Björk, 2018).

The sharing economy concept has also emerged in the tourism marketplace (Sthapit and Jiménez-Barreto, 2018a). In the sharing economy, businesses utilise information technology to connect consumers with demands to providers with excess capacity (Gonzalez-Padron, 2017; Leung et al., 2019). Businesses based on the sharing economy concept in service contexts like transportation, for example, Uber, continue to grow at a phenomenal rate. These companies based on the sharing economy pose new threats to the traditional tourism industry (Abrate and Viglia, 2019). The rise of profit-based online platforms for peer-to-peer sharing such Uber has changed the way people travel and is of great significance to the traditional tourism industry $(\mathrm{HeO}, 2016)$. Uber operates in around 400 cities worldwide and has gained prominence in the tourism industry including partnering with traditional tourism service providers such as Hilton to provide a seamless travel experience and enhance the guest experience (OECD, 2016). In addition, many transportation service providers have shifted their focus from service delivery to the experience co-creation (Chathoth et al., 2016). This shift towards experience co-creation also applies to Uber. Uber is the most noticeable example of the sharing economy that "has taken a dramatic amount of business from taxi firms in cities where it operates around the world" (Zhu et al., 2017, p. 2219). Uber is an online platform created and developed by Uber Technologies Inc., which enables its user to offer, share and request rides. Recent studies on the sharing economy have predominantly focussed on its benefits in hospitality and other sectors (Smaliukiene et al., 2015) and are conducted specifically in the context of Airbnb (Sthapit and Jiménez-Barreto, 2018a, 2018b). In the same vein, studies elaborating on the value co-destruction concept have been limited to Airbnb setting (Sthapit, 2018a; Sthapit and Jiménez-Barreto, 2018b). Despite the increasing interest in the sharing economy, to date, there has been a paucity of studies examining customers Uber experience (Breidbach and Brodie, 2017; Heinrichs, 2013; Lee et al., 2018; Leung et al., 2019). In addition, to the best of our knowledge, there are no studies linking the concept of value co-destruction in the context of Uber, thereby revealing a lacuna.

Moreover, although some studies indicate that Uber is more convenient and comfortable and gives customers better experiences than traditional taxi services (Rayle et al., 2016), it has also come under increasing scrutiny as a result of customers being exposed to risks other than monetary loss (Lauterbach et al., 2009). A recent unfortunate example is the experience of a woman who was raped by an Uber driver (The Guardian, 2018). Given that 
the same offering may produce a different level of value for different people (Vargo and Lusch, 2008), and that as a result of this some people are worse off (co-destruction) (Echeverri and Skålen, 2011; Plé, 2017), the situation poses interesting and largely unexplored questions.

The present study seeks to address this research gap by exploring the antecedents of value co-destruction in the context of Uber. The research question this study aims to answer is the following: What are the antecedents of value co-destruction in the context of Uber from a customer's perspective? This service sector was considered a good place to undertake the current study because firms usually attempt to strengthen relations with their consumers (Randall, 1997). This study employed netnography for data collection. The study is based on online reviews of customers' experiences with Uber. Out of the total 758 review posts that were manually extracted, 75 negative reviews were analysed in this study. The keywords "bad", "terrible" and "awful" were used to select online posts linked to value co-destruction outcomes of IVF for Uber.

\section{Literature review}

\section{Sharing economy, its impact on the tourism industry and Uber}

The term "sharing economy" denotes the "collaborative consumption made by the activities of sharing, exchanging, and rental of resources without owning the goods" (Lessig, 2008, p. 143). The sharing economy builds on the ideology of making good use of underused resources among consumers and is characterised by peer-to-peer transactions. These marketplaces are defined by direct transactions between individuals (buyers and sellers) (Botsman and Rogers, 2011). The growth of ICT makes it possible for entrepreneurs to scale up the sharing economy in a virtual marketplace (Katz, 2015). In addition, ICT is a facilitator that allows tourists to better communicate and interact (Buhalis and Law, 2008) and has evolved as integral tools enabling contemporary experience co-creation (Dorcic et al., 2019; Tussyadiah and Wang, 2016). In recent years, the sharing economy has seen unprecedented growth in terms of user numbers, enabling new avenues of economic and social interaction (Sundararajan, 2016). Moreover, the impact of the sharing economy on tourism has come to recent attention largely because of the speed at which it is growing and recent valuations of companies such as Uber (Dredge and Gyimóthy, 2015; Ert et al., 2016). As an emerging business model, the sharing economy is puzzling the landscape of tourism (Cheng et al., 2019). Moreover, the sharing economy can be closely linked to the concept of smart tourism that focuses on application of technology in the tourism industry (Li et al., 2017).

Uber is a mobile ride request corporation started by Travis Kalanick and Garrett Camp in 2009 (Ngo, 2015). Uber is based in San Francisco, CA, USA, and has become one of the biggest and fastest developing businesses in the evolving ride-sourcing industry within the new and larger sharing economy (Alley, 2016). Uber can be considered as an online transportation network company that develops, markets, and operates the Uber smartphone app, allowing consumers with smartphones to submit a trip request routed to Uber partnered drivers driving their private cars. In addition, Uber does not own a fleet of cars (Wang and $\mathrm{Mu}, 2018$ ). Uber constitutes a low-cost substitute to the services provided by the traditional taxi sector. The low-end services provided by Uber are cheaper due to its efficient matching system between drivers and passengers, the absence of requirements for its drivers to obtain costly taxi medallions, and it's pricing being handled by a dynamic algorithm (Cramer and Krueger, 2016).

\section{Value co-destruction}

One possible outcome of the collaboration between different actors involved in a service process is value co-destruction (Echeverri and Skålen, 2011; Plé and Cáceres, 2010; 
Smith, 2013). Plé and Cáceres (2010) were the first to coin the term in an service-dominant logic context, and they define value co-destruction as "[... an interactional process between service systems that results in a decline in at least one of the systems' wellbeing [...]"'(Plé and Cáceres, 2010, p. 431). Value co-destruction is interactional between a firm and a customer (Prior and Marcos-Cuevas, 2016). Interaction refers to resource exchange and resource development through adaptation, coordination and communication (Gummesson and Mele, 2010). Actors are part of service systems and are described as "configurations of people, technology, value propositions connecting internal and external service systems, and shared information" (Maglio and Spohrer, 2008, p. 18). In addition, interactions can be direct (e.g. person-to-person interactions) or indirect (e.g. interactions via appliances such as goods or services) (Plé, 2017). More specifically, value co-destruction is a failed interaction process that has a negative outcome: it leads to a decline in well-being, which can take the form of frustration or lost resources for a service provider or customer (Prior and Marcos-Cuevas, 2016). The decline in well-being refers to intangible matters (such as negative feelings) and tangible matters (as in lost resources, such as money) (Makkonen and Olkkonen, 2017). According to Smith (2013) value co-destruction occurs even if only the potential enhancement of well-being has not been met. In addition, Echeverri and Skålen, (2011) have carried out one of the few empirical studies investigating value co-destruction. They study the interaction between employees of a public transport enterprise and its customers. In their view, value co-destruction occurs "when the elements of practices are incongruent-i.e. when providers and customers do not agree on which procedures, understandings and engagements should inform a specific interaction [...]" (Echeverri and Skålen, 2011, p. 367). Moreover, a recent study by Sthapit and Jiménez-Barreto (2018b) in the context of tourism, in particular, Airbnb, identified poor communication between the Airbnb guest and host as an antecedent of value co-destruction.

Previous studies on value co-destruction focussed on introducing the concept of co-destruction (Plé and Cáceres, 2010), co-creation and co-destruction (Echeverri and Skålen, 2011) and the value co-destruction process (Smith, 2013). Current studies have examined value co-destruction in the context of interfirm relationships (Makkonen and Olkkonen, 2017; Prior and MarcosCuevas, 2016), hotels (Sthapit and Björk, 2018), the banking sector (Kashif and Zarkada, 2015), sports management (Stieler et al., 2014), online channels (Quach and Thaichon, 2017; Zhang et al., 2018), bike sharing (Yin et al., 2018) and social media in tourism (Dolan et al., 2019), including the reasons that lead to value co-destruction (Järvi et al., 2018; Vafeas et al., 2016) and the need for research on this topic (Echeverri and Skålen, 2011; Plé, 2017; Prior and Marcos-Cuevas, 2016; Sthapit and Björk, 2018; Vafeas et al., 2016). In the context of the sharing economy, studies elaborating on the value co-destruction concept have been limited to Airbnb setting (Sthapit, 2018a; Sthapit and Jiménez-Barreto, 2018b), while ridesharing companies like Uber have received less research attention.

\section{The concept of value, operand and operant resources and resource loss in the value co-destruction process}

The value in service-dominant logic is generated by the collaborative actions of co-creation between customers and brands/organisations (Grönroos and Voima, 2013). Consumers' achievement of goodness could be considered equivalent to the capturing of consumer value (Ravald and Grönroos, 1996). A frequently cited definition is that value is "the consumer's overall assessment of the utility of a product based on perceptions of what is received and what is given" (Zeithaml, 1988, p. 14), while in line with S-D logic, Vargo et al. (2008, p. 149) defined value as "an improvement in system well-being", which can be measured "in terms of a system's adaptiveness or ability to fit in its environment". In the same vein, value is considered a key variable for analysing consumer behaviour (Gallarza and Gil, 2008). In this paper, we adopt a hybrid definition of value. We define value as benefits versus sacrifices and an improvement in system (customer) well-being. In addition, this study takes emotional reactions as the starting point in exploring the antecedents of value co-destruction.

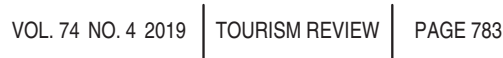


Value is uniquely determined by the beneficiary (customer) in a particular context (Chandler and Vargo, 2011) and is closely tied to consumer experience (Lusch and Vargo, 2014). Therefore, it is customers themselves who actively co-create with companies, integrate operand and operant resources and extract value in context and in use (Morosan and DeFranco, 2016). Value is facilitated through a value proposition when applying intangible competences (operant resources), such as human skills and knowledge, and tangible elements (operand resources), such as physical products and equipment that require the action of operant resources. On the contrary, operant resources not only co-create but also co-destroy value (Echeverri and Skålen, 2011). On one hand, operand resources are those on which an operation or an act is performed to produce an effect (Constantin and Lusch, 1994) and are typically physical (e.g. raw materials) (Hunt, 2004). On the other hand, operant resources are employed on operand resources (Wieland et al., 2012), and value is conceptualised as realised in use. Operant resources are typically human (e.g. the skills and knowledge of individual employees), organisational (e.g. controls, routines, cultures and competences), informational (e.g. knowledge about market segments, competitors, and technology), and relational (e.g. relationships with competitors, suppliers, and customers) (Hunt, 2004). It is only when the knowledge and skills, or the operant resources, are active or activated that value co-creation takes place. Contrary to the exchange view of value for emphasising operand resources as central to the value formation process, operant resources are key to value co-creation. (Echeverri and Skålen, 2011).

According to Smith (2013) the conservation of resources theory (Hobfoll, 1989) addresses the impact of resource loss on the individual's well-being and provides valuable insights into the value co-destruction process from the customer's perspective. Hobfoll's (2002) classification of resources includes material resources (functional tangible and/or intangible objects, e.g. food or telecoms service); conditions (respondents' perceptions of how the encounter affected their own status in the eyes of others); self (self-esteem and self-efficacy); social (emerges from the environment and involves perceptions of receipt of support, such as the degree of helpfulness and concern as perceived by the respondent); and energies (time, money and knowledge, including costs of physical and emotional effort).

\section{The link between emotions and value}

Tourism experiences include a strong affective (i.e. emotional) component (Coghlan and Pearce, 2010). Emotions have been identified as a key customer resource in the value creation process (Rodie and Kleine, 2000). As value can emerge from mental and emotional experiences (Heinonen et al., 2010) and resides "not in an object, a product or a possession but rather in and only in a consumption experience" (Holbrook, 1999, pp. 8-9), emotions form an important part of consumption experiences (Holbrook and Hirschman, 1982). Successful co-creation is a source of positive emotions such as pride (Moreau and Herd, 2010), while failed service encounters (value co-destruction) often result in negative emotions (Schoefer and Ennew, 2005), such as guilt (Sugathan et al., 2017) and anger (Smith, 2013). As mentioned earlier, value is also defined as an improvement in system wellbeing (Vargo et al., 2008), and unpleasant emotions are linked to a negative component of subjective well-being (Diener et al, 1999). In addition, negatively valenced engagement can be exhibited through customers' unfavourable thoughts, feelings and behaviours toward the brand during interactions (Hollebeek and Chen, 2014).

\section{Methodology \\ Data collection and analysis}

The present study adopts netnography in the form of non-participant observation for data collection and is based on online reviews about customers' Uber experiences published on the site TrustPilot. According to Kozinets (2002), netnography is broadly based on the reflexive 
narratives that people publish online. He has defined netnography as a process and as a "new qualitative research methodology that adapts ethnographic research techniques to study the cultures and communities that are emerging through computer-mediated communications" (Kozinets, 2002, p. 62). Netnography was considered appropriate for this study because customers usually write their reviews after their rides end, so their experiences are not affected by observations (Kozinets, 2002). In addition, netnography is relatively rapid, simple and inexpensive, allowing access to naturalistic, unprompted insider experiences, perspectives and reflections and capturing the exchange of tourism information on the Internet (Mkono and Markwell, 2014). Data can be collected from numerous sources, such as traveller blogs and online tourist reviews that include chat forums and social networking sites, and are analysed thematically (Catterall and Maclaran, 2001). Kozinets (2010) suggests that pure netnography is self-contained and requires no off-line ethnographic research.

This study follows Kozinets's (2002) guidelines for conducting netnography. These guidelines are discussed below. The first step involves identifying the online communities most relevant to a researcher's particular research interest as well as learning as much as possible about the communities that are identified. Netnography in the form of non-participant observation is used in this study and is based on Internet customer reviews that contain detailed information about their experiences of Uber. The reason for choosing non-participant observation is the undesirable influence of outsiders on the group (Elliott and Jankel-Elliot, 2003). The researcher intensively reviewed websites offering online consumer reviews about their experiences, both positive and negative, with Uber. The search for convenient web sites for this study was conducted on Google using combinations of the following keywords: "tourists Uber experience" and "visitor Uber experience". In the process of finding online communities with positive and negative review posts on the internet, the search revealed two websites: TripAdvisor and TrustPilot. However, the TripAdvisor website contained extremely few review posts compared to TrustPilot for data collection and analysis. Thus, review posts in TrustPilot website was used for data collection and analysis. The second step of netnography involves data collection. Data collection and analysis were conducted from December 2017-March 2018. A total of 758 online posts were reviewed. Negative emotional words that are commonly used: "bad", "terrible" and "awful", were indicative of the destructive outcome of the IVF. However, this study acknowledges that throughout the course of a service experience, customers experience a variety of emotions (Torres et al., 2017). Therefore, the use of only three negative emotional words is one of the main limitations and that there are also other options, for example, negative, unsatisfactory and horrible. A total of three keywords were used to search TrustPilot forums to avoid overwhelming amounts of data. Irrelevant reviews and messages were omitted from the analysis to ensure analytical depth and a focus on the topic. Each narrative consisted of one "entry" and one or several "comments/responses". In all, out of 758 reviews, 75 were included in the study based on the keywords: bad (10), terrible (52) and awful (13). On average, each review contained four sentences.

The third step in netnography is linked to the ethics of the researcher's role. When researchers enter an active online community as participant observers, querying and directing communication, they should fully disclose their identities and motives, obtain informed consent and conduct member checks with key informants (Wu and Pearce, 2014). However, when accessing blogs or review sites as non-participant observers, there is no compelling need to communicate research objectives or obtain consent as the data are available on public (sometimes anonymous) Internet fora, and the posts have often been made months or years in the past (Mkono, 2012). The covert netnographic approach applied here supports a high personal level of and social distance between the researchers and subjects (Arsal et al., 2010). To ensure the trustworthiness of the study, we have explained all the phases of our research in detail (how the data were collected, categorised and analysed). In addition, the web sites utilised in this study are established as public forums of communication, meaning that consent is unnecessary for the analysis of public postings. 
A grounded theory research design (Glaser and Strauss, 1967) was used to analyse the collected data. This approach allows themes and issues that participants deem important to emerge. The collected data were first scanned for a broad understanding. This was followed by reading the online narratives and categorising the value dimensions, resulting in three different outcomes. In the last step, three types of coding work (open coding, axial coding and selective coding) (Strauss and Corbin, 1990) were performed manually. Ethnography and grounded theory are methodological complements (Glaser and Strauss, 1967) and share the constructivist principle that truth and reality relate to the perceptions of an individual. This means that although some of the practical mechanics of each methodology differ, they form a potent strategy when used in combination (Charmaz and Mitchell, 2001). In addition, grounded theory formalises and extends the limited theoretical component of ethnography (Pettigrew, 2000).

\section{Findings}

Out of the 75 reviews included in the study, the majority of the sample were domestic Uber customers (58), while others included tourists (17). An analysis of the findings from the grounded theory research design related to customers' negative experiences with Uber and their causes, are discussed in the following section. The coding process inductively identified two emerging antecedents of value co-destruction in the context of Uber.

\section{Uber drivers' bad behaviour}

The majority of review posts stressed that Uber drivers' bad behaviour triggered value codestruction during both the pre-taxi service and the taxi experience. Given that the person who provides a service is an integral part of the experience in transportation services (Ert et al., 2016) and that both providers and customers are involved in realising the service delivery (Echeverri and Skålen, 2011), customers experienced value co-destruction during both the pre-taxi service and the taxi experience. Table I illustrates the interpretive codes around the significance of Uber drivers' bad behaviour contributing to value co-destruction.

The axial coding (Strauss and Corbin, 1990) of subthemes of personal behaviour (such as not being on time, offensive language, poor communication, ignorance, cancellation and overcharging) helped to connect the codes to form the main theme and describe the antecedent(s) of value co-destruction in the context of Uber: drivers' bad behaviour. The following two review posts about negative Uber experiences can be linked to the subthemes that helped to form the main theme:

Terrible. Never in 30 years have I ever had a driver be so rude and ignorant. First and last time l'll ever use this rubbish thing they call a taxi company. Driver was racist and should have his license took away. He was so rude just because I pointed out that he missed a turning [...] Don't use them. (Jane; review published on 1 January 2018)

Table I The coding process in practice (main theme 1: Uber driver's bad behaviour)

Open Coding

(line-by-line coding)
Subthemes

(axial coding)
Main themes (selective coding) "terrible and did not turn up", "made me late for my appointment", "terrible driver", "terrible experience", "journey was horrible and price of this was terrible", "terrible service", "absolutely terrible", "being stranded in the middle of nowhere", "long waiting time for the driver, problem with the Uber application", "racist, rude and ignorant behaviour of the drive", "incorrect maps used by the driver", "poor driving skills of the driver", "poor communication", "erratic and unsafe driving", "ignoring of navigator and directions by the driver", "taking of long route to overcharge the customer", "overcharging", and "cancellation fees for unused trips"
Uber drivers' personal Uber drivers' bad behaviour behaviour, not in time, is an antecedent of value offensive language, co-destruction poor communication, ignorance, cancellation and overcharging 
Terrible experience with Uber service today. The rider accepted my ride request but never showed up and ignored my calls and text messages. My App showed he was sitting near a shopping plaza a mile away instead of picking me up. After 35 minutes in the heat, my cell phone died and I had to take a taxi. Terrible service [.. . ]. (May; review published on 6 September 2017)

These review posts clearly illustrate incongruent understandings between a driver and a customer. Ultimately, customers failed to experience value during the interaction process because the integration of the available resources of one service system (the Uber driver's bad behaviour) is considered inappropriate by the other interacting service system (the Uber customer). This resulted in the decline of the customer's well-being because of the unexpected resource loss - for example, physical and emotional (customer's own tangibles and efforts), financial (monetary cost) and temporal (time spent), also described as energies (Hobfoll, 1989). First, physical effort was linked to activities involving contacting the Uber driver through telephone and text messages. Second, some had expended emotional energy in dealing with offensive language, poor communication, ignorance, cancellation and overcharging, which resulted in an expression of negative affect. These expressions suggest a negative component of subjective well-being (Diener et al., 1999). Third, unexpected time expenditure included long waits for the taxi. Customer waiting time has a negative influence on consumer service perception. Service companies may lose transaction if the wait time is too long (Bielen and Demoulin, 2007). Fourth, loss of financial resource was linked to being overcharged and having to pay for a service not received - that is, a taxi ride.

Uber's value proposition of "the best way to get around" did not hold up for many guests and represented a failed resource offer (value proposition). The customers felt that the driver was unable to fulfil Uber's resource offer (value proposition) and created unmet expectations, generating negative emotions. The failure to meet expectations created discrepancies between desired actual states. In fact, customers felt that they received less than had been expected. The consequent uncertainty and lack of clarity caused worry and anxiety among the customers and impacted negatively on well-being. Studies indicate that a key aspect of collaboration is that the provider can serve the customer in the way that the customer expects and it is valuable for the customer (Järvi et al., 2018). The review posts also indicate that, from a customer perspective, a Uber driver deliberately generated value imbalance to his or her benefit by nonintegrating resources when interacting with customers (for example, waiting for the customer to cancel the order at the last minute in order to charge a cancellation fee for the trip).

This can be further linked to the concept of service failure resulting in customers' economic and/ or social loss in exchanges. Service failure refers to a situation in which there is a problem in providing the intended service to the customer (Roggeveen et al., 2012) and is normally detected by the customer first (Vaerenbergh and Orsingher, 2016). Skourtis et al. (2016) re-conceptualise service failures as co-destruction moments due to the fact that when a service failure occurs, some forms of consumption value (functional, social, emotional, epistemic and conditional) are co-destroyed (co-destructionmoment) - similar to the way they are co-created during value cocreation. In the context of this study, the level of service failure varied in gravity from being something serious, such as waiting for four hours for an Uber taxi, to something trivial, such as a short delay. In addition, because of the service failure, some customers experienced a net deficit, the difference between perceived benefits and costs from the interaction in which excessive costs can be psychological and emotional (Prior and Marcos-Cuevas, 2016).

\section{Uber's poor customer service}

Another major emerging theme that triggered value co-destruction in the post-consumption phase is Uber's poor customer service. Table II illustrates the interpretive codes around the significance of Uber's poor customer service, contributing to value co-destruction.

This is highlighted by the responses of two reviewers: 
"customer service is terrible", "they never contacted me back", "does not even respond to aid their users", "designed to avoid human contact", "their email system doesn't work", "no body speaks English", "rude, and hang up on you", "yet to receive a response", "horrible customer service", "worst customer service ever", "terrible customer service", "kept getting automated messages", "worst customer service", "customer service is terrible beyond belief", "customer service is non-existent", "shocked at how shameful Uber's customer service is", "bad customer service", "lack of customer service" and "customer service simply lies"

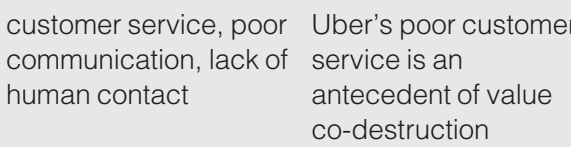
communication, lack of service is an human contact antecedent of value co-destruction

UBER's customer service is terrible beyond belief. I have tried to contact them numerously over the past 2 months and they have never contacted me back. My account has been deactivated for nonsense for the past few months and UBER failed to mention how I can regain access to my account. I logged onto my account on my computer [...] there is no outstanding balance for me to fulfil. This company does not even respond to emails to aid their users who have been loyal for years. What a shame. (Lior, Review published on 13 March 2018)

I called customer service, nobody really speaks English, they are rude, and hang up on you as soon as they find out that you actually have a complaint. They promised to call back in case we get disconnected, they of course didn't [...] I used to love Uber, but after this experience I will never ride with them again. (Chemitry1, Review published on 14 July 2016)

The review posts indicate that value co-destruction is present because the interaction between the customer and the firm (customer service department personnel) was not successful. In fact, customers' failure to experience value continued after a service failure as Uber's customer service failed to satisfactorily resolve problems. This resulted in further losses of customers' resource (time, money, self-esteem and self-efficacy; Hobfoll, 1989), which led to a decline in well-being. For example, customers continued in their efforts to reclaim their lost resources, incurring additional losses of energy (time and money) by contacting Uber customer service by telephone or email. However, they felt helpless because of the poor feedback and not being able to have a human interaction, including inactive customer service emails and the rude behaviour of customer service personnel. This further amplified their negative Uber experience, and, as a result, some customers mentioned that they would stop using the service.

Uber's customer service personnel's rude behaviour negatively influenced customers' selfesteem, and failure to receive information led to confusion and a perceived reduction in selfefficacy. Hobfoll (2002) categorises self-esteem and self-efficacy as resources. Self-esteem relates to "judgements of self-worth" (Bandura, 1997, p. 11) and is reflected in subjective feelings, focussing on "l" rather than "they" (for example, feeling good about oneself) (Smith, 2013). Self-efficacy is about "belief in personal capability" (Bandura, 1997, p. 11). Moreover, an important aspect of customer service is communicating with customers (skill, an operant resource); however, the poor communication skills of the service personnel and the lack of communication at the macro (company) level led to the customer feeling devalued.

\section{Conclusion}

This study is one of the first empirical studies to shed light on the antecedents of value codestruction in the context of Uber. The overarching aim of this study was to elucidate the sources that generate value co-destruction in the sharing economy context, particularly Uber, based on online review posts linked to customers' negative experiences with Uber. 
The main contributions to the theory by the present work includes the antecedents of value codestruction in the context of Uber. Here, the antecedents of value co-destruction was discovered to comprise two main dimensions: Uber driver's bad behaviour and Uber's poor customer service. The emerging antecedents contributed to customer's unexpected resource losses (physical, emotional, financial and temporal), which led to a decline in well-being. Interpretive codes such as "no empathy", "what a shame", "poor", "will never ride with them again", "disgusting" and "not acceptable" are indicative of reviewer's loss of well-being. In addition, reviewers perceived Uber drivers' misuse of their own resources, for example overcharging or imposing excessive waiting times.

From a micro level perspective, Uber drivers were unable to serve what the customers expected, then value co-destruction emerged. There was a lack of empathy and of responsiveness shown by the Uber drivers. At the macro level, as a result of the value codestruction, some customers tried to restore their resources by contacting Uber customer service, which was also unsuccessful. As a result, customers faced indifferent attitudes, cheating, lack of a complaint outlet and delayed service recovery. For some customers, the service recovery process was a failure and led to decline in well-being. In addition, for some, the decline in well-being was so significant that they vowed not to use Uber in the future and to tell their friends and relatives about their negative experiences. The findings are in contrast to studies indicating that, because of taxi services such as Uber, waiting times have been dramatically shorter than those associated with traditional taxis (Rayle et al., 2016), which are not considered to be as cheap and convenient a transportation option. Alternatively, the findings support studies indicating that customer service is an important activity contributing to the success of organisations through customer loyalty, increased cash flow and revenue and market added value (Schneider et al., 2007).

This study argues that it is not the Uber mobile application that is of significance to customers' well-being during the overall Uber experience; it is the good behaviour of Uber drivers and prompt Uber customer service that matters the most. In other words, the mobile application is the operand resource upon which good communication skills (operant resources) act to produce benefits to customers, such as greater speed of service, shorter waiting times and higher levels of convenience.

Another contribution of this study is the use of netnography and a grounded theory research design to uncover the antecedents of value co-destruction, which helped the researcher to gain more understanding of the topic. Few studies have used netnography (Smaliukiene et al., 2015) or grounded theory in sharing economy studies (Sthapit and Jiménez-Barreto, 2018a, 2018b), and such an approach should therefore set a new standard for research conducted in this field.

From a managerial perspective, Uber's management should invest more in resources to minimise the negative experiences of its customers (both domestic customers and tourists) by clearly defining the drivers' tasks and responsibilities. If the drivers' tasks are unclear, then customers cannot be served in an effective manner and with consistent service quality. The Uber drivers, regardless of their full-time or part-time work shifts, should ensure that quality services are offered to customers. Providing high-quality service might reduce the number of complaints and result in positive comments and compliments. Tourists now have more ways to demonstrate behaviour that will negatively impact firms by posting negative reviews online (Plé and Cáceres, 2010). The negative review posts analysed in this study are an example of negative word-of-mouth, another coping strategy (Yi and Baumgartner, 2004) that may incur loss of well-being for Uber, such as financial loss because of customers switching from one taxi service provider to another and warning other potential customers against using the service. In addition, when customers report their dissatisfaction, Uber's management should instruct the customer service personnel that such dissatisfaction should be dealt with promptly and effectively through good customer service. Uber's management should also focus on successful recovery efforts after a service failure (for example, tangible compensation and apology), which may lead to improved satisfaction. Moreover, based on financial performance, Uber's 
management should not blindly trust that all its customers are having a positive taxi experience; the focus must also be on the customer perceiving benefits as well.

The researcher attempted to expand the existing understanding of the antecedents of value co-destruction in the context of Uber. Although the endeavour was worthwhile, it was not without its limitations. First, the netnography study, by its nature, was restricted to those customers who shared their reviews online. The study did not consider those customers who have not posted their reviews online. Second, the focus of the study was on customer reviews that were written in English. Third, only three keywords ("bad", "terrible" and "awful") were used in the data selection process, limiting the number of review posts (75) that were analysed in this study. In addition, even if this study does not produce statistically generalisable findings, the findings are valuable in an analytical sense.

A recent study by Makkonen and Olkkonen (2017), Sthapit and Björk (2018) and Sthapit (2018b) offers evidence of a third outcome, value no-creation, in which the expectations of resource integration and the respective values-in-context remain unrealised. In addition, Makkonen and Olkkonen (2017) explain that three value outcomes together guide "toward clarified terminology and an integrative perspective to bridge the research on value cocreation and co-destruction" (p. 518). Future studies should examine the value dimensions that generate three types of value outcomes as a result of IVF: value co-creation, value codestruction and value no-creation in the context of Uber. Such an approach would broaden the understanding of the concept of value beyond value co-creation and co-destruction.

\section{References}

Abrate, G. and Viglia, G. (2019), "Personal or product reputation? Optimizing revenues in the sharing economy", Journal of Travel Research, Vol. 58 No. 1, pp. 136-148.

Alley, J.K. (2016), "The impact of Uber technologies on the New York city transportation industry", Unpublished undergraduate project, University of Arkansas, Fayetteville.

Arsal, I., Woosnam, K.M., Baldwin, E.D. and Backman, S.J. (2010), "Residents as travel destination information providers: an online community perspective", Journal of Travel Research, Vol. 49 No. 4, pp. 400-413.

Bandura, A. (1997), Self-Efficacy: The Exercise of Control, Freeman W.H. and Company, New York, NY.

Bielen, F. and Demoulin, N. (2007), "Waiting time influence on the satisfaction-loyalty relationship in services", Managing Service Quality: An International Journal, Vol. 17 No. 2, pp. 174-193.

Botsman, R. and Rogers, R. (2011), What's Mine Is Yours: How Collaborative Consumption Is Changing the Way we Live, Collins Publishing, London.

Breidbach, C.F. and Brodie, R.J. (2017), "Engagement platforms in the sharing economy: conceptual foundations and research directions", Journal of Service Theory and Practice, Vol. 27 No. 4, pp. 761-777.

Buhalis, D. and Law, R. (2008), "Progress in information technology and tourism management. 20 years on and 10 years after the internet: the state of etourism research", Tourism Management, Vol. 29 No. 4, pp. 609-623.

Bustard, J.R.T., Bolan, P., Devine, A. and Hutchinson, K. (2019), "The emerging smart event experience: an interpretative phenomenological analysis”, Tourism Review, Vol. 74 No. 1, pp. 116-128.

Catterall, M. and Maclaran, P. (2001), "Body talk: questioning the assumptions in cognitive age", Psychology and Marketing, Vol. 18 No. 10, pp. 1117-1133.

Chandler, J. and Vargo, S.L. (2011), "Contextualization: network intersections, value-incontext, and the co-creation of markets", Marketing Theory, Vol. 11 No. 1, pp. 35-49.

Charmaz, K. and Mitchell, R.G. (2001), "Grounded theory in ethnography", in Atkinson, P., Coffey, A., Delamont, S., Lofland, J. and Lofland, L. (Eds), Handbook of Ethnography, Sage, London, pp. 160-174.

Chathoth, P., Ungson, G., Harrington, R. and Chan, E. (2016), "Co-creation and higher order customer engagement in hospitality and tourism services", International Journal of Contemporary Hospitality Management, Vol. 28 No. 2, pp. 222-245. 
Cheng, X., Fu, S., Sun, J., Bilgihan, A. and Okumus, F. (2019), "An investigation on online reviews in sharing economy driven hospitality platforms: a viewpoint of trust", Tourism Management, Vol. 71, pp. 366-377.

Coghlan, A. and Pearce, P. (2010), "Tracking affective components of satisfaction", Tourism and Hospitality Research, Vol. 10 No. 1, pp. 1-17.

Constantin, J.A. and Lusch, R.F. (1994), "Understanding resource management", The Planning Forum, Oxford, $\mathrm{OH}$.

Cramer, J. and Krueger, A.B. (2016), "Disruptive change in the taxi business: the case of Uber", American Economic Review, Vol. 106 No. 5, pp. 177-182.

Diener, E., Suh, E.M., Lucas, R.E. and Smith, H.L. (1999), "Subjective well-being: three decades of progress", Psychological Bulletin, Vol. 125 No. 2, pp. 276-302.

Dolan, R., Seo, Y. and Kemper, J. (2019), "Complaining practices on social media in tourism: a value cocreation and co-destruction perspective", Tourism Management, Vol. 73, pp. 35-45.

Dorcic, J., Komsic, J. and Markovic, S. (2019), "Mobile technologies and applications towards smart tourism - state of the art", Tourism Review, Vol. 74 No. 1, pp. 82-103.

Dredge, D. and Gyimóthy, S. (2015), "The collaborative economy and tourism: critical perspectives, questionable claims and silenced voices", Tourism Recreation Research, Vol. 40 No. 3, pp. 286-302.

Echeverri, P. and Skålen, P. (2011), "Co-creation and co-destruction: a practice-theory based study of interactive value formation", Marketing Theory, Vol. 11 No. 3, pp. 351-373.

Elliott, R. and Jankel-Elliot, N. (2003), "Using ethnography in strategic consumer research", Qualitative Market Research: An International Journal, Vol. 6 No. 4, pp. 215-223.

Ert, E., Fleischer, A. and Magen, N. (2016), "Trust and reputation in the sharing economy: the role of personal photos on Airbnb", Tourism Management, Vol. 55, pp. 62-73.

Gallarza, M.G. and Gil, I. (2008), "The concept of value and its dimensions: a tool for analysing tourism experiences", Tourism Review, Vol. 63 No. 3, pp. 4-20.

Glaser, B.G. and Strauss, A. (1967), The Discovery of Grounded Theory: Strategies for Qualitative Research, Aldine, Chicago.

Gonzalez-Padron, T.L. (2017), "Ethics in the sharing economy: creating a legitimate marketing channel", Journal of Marketing Channels, Vol. 24 Nos 1/2, pp. 84-96.

Grönroos, C. (2012), "Conceptualising value co-creation: a journey to the 1970 s and back to the future", Journal of Marketing Management, Vol. 28 Nos 13/14, pp. 1520-1534.

Grönroos, C. and Voima, P. (2013), "Critical service logic: making sense of value creation and cocreation", Journal of the Academy of Marketing Science, Vol. 41 No. 2, pp. 133-150.

Gummesson, E. and Mele, C. (2010), "Marketing as value co-creation through network interaction and resource integration", Journal of Business Market Management, Vol. 4 No. 4, pp. 181-198.

Heinonen, K., Strandvik, T., Mickelsson, K.-J., Edvardsson, B., Sundström, E. and Andersson, P. (2010), "A customer-dominant logic of service", Journal of Service Management, Vol. 21 No. 4, pp. 531-548.

Heinrichs, H. (2013), "Sharing economy: a potential pathway to sustainability", GAIA, Vol. 22 No. 4, pp. 228-231.

Heo, C.Y. (2016), "Sharing economy and prospects in tourism research", Annals of Tourism Research, Vol. 58, pp. 166-170.

Hobfoll, S.E. (1989), "Conservation of resources: a new attempt at conceptualizing stress", American Psychologist, Vol. 44 No. 3, pp. 513-524.

Hobfoll, S.E. (2002), "Social and psychological resources and adaptation", Review of General Psychology, Vol. 6 No. 4, pp. 307-324.

Hollebeek, L.D. and Chen, T. (2014), "Exploring positively versus negatively-valenced Brand engagement: a conceptual model", Journal of Product \& Brand Management, Vol. 23 No. 1, pp. 62-74.

Holbrook, M.B. (1999), Consumer Value: A Framework for Analysis and Research, Routledge, New York, NY.

Holbrook, M.B. and Hirschman, E.C. (1982), "The experiential aspects of consumption: consumer fantasies, feelings, and fun", Journal of Consumer Research, Vol. 98 No. 2, pp. 132-141. 
Hunt, S.D. (2004), "On the service-centered dominant logic of marketing", Journal of Marketing, Vol. 68 No. 1, pp. 21-22.

Järvi, H., Kähkönen, A.-K. and Torvinen, H. (2018), "When value co-creation fails: reasons that lead to value co-destruction", Scandinavian Journal of Management, Vol. 34 No. 1, pp. 63-77.

Kashif, M. and Zarkada, A. (2015), "Value co-destruction between customers and frontline employees: a social system perspective”, International Journal of Bank Marketing, Vol. 33 No. 6, pp. 672-691.

Katz, V. (2015), "Regulating the sharing economy", Berkeley Technology Law Journal, Vol. 30 No. 4, pp. 10-67.

Kirillova, K. and Wang, D. (2016), "Smartphone (dis)connectedness and vacation recovery", Annals of Tourism Research, Vol. 61, pp. 157-169.

Kozinets, R.V. (2002), "The field behind the screen: using netnography for marketing research in online", Journal of Marketing Research, Vol. 39 No. 1, pp. 61-72.

Kozinets, R. (2010), Netnography: Doing Ethnographic Research Online, Sage, London.

Lauterbach, D., Truong, H., Shah, T. and Adamic, L.A. (2009), "Surfing a web of trust: reputation and reciprocity on CouchSurfing.com", Proceedings IEEE CSE'09, 12th IEEE International Conference on Computational Science and Engineering, Vancouver, BC.

Lee, Z.W.Y., Chan, T.K.H., Balaji, M.S. and Chong, A.Y.-L. (2018), "Why people participate in the sharing economy: an empirical investigation of Uber", Internet Research, Vol. 28 No. 3, pp. 829-850.

Lessig, L. (2008), Remix: Making Art and Commerce Thrive in the Hybrid Economy, Penguin Press, New York, NY

Leung, X.Y., Xue, L. and Weh, H. (2019), "Framing the sharing economy: toward a sustainable ecosystem", Tourism Management, Vol. 71, pp. 44-53.

Li, Y., Hu, C., Huang, C. and Duan, L. (2017), "The concept of smart tourism in the context of tourism information services”, Tourism Management, Vol. 58, pp. 293-300.

Lusch, R.F. and Vargo, S.L. (2014), Service-Dominant Logic: Premises, Perspectives, Possibilities, Cambridge University Press, Cambridge.

Maglio, P.P. and Spohrer, J. (2008), "Fundamentals of service science", Journal of the Academy of Marketing Science, Vol. 36 No. 1, pp. 18-20.

Makkonen, H. and Olkkonen, R. (2017), "Interactive value formation in interorganizational relationships: dynamic interchange between value co-creation, no-creation, and co-destruction", Marketing Theory, Vol. 17 No. 4, pp. 517-535.

Mkono, M. (2012), "Netnographic tourist research: the internet as a virtual fieldwork site", Tourism Analysis, Vol. 17 No. 4, pp. 553-555.

Mkono, M. and Markwell, K. (2014), "The application of netnography in tourism studies", Annals of Tourism Research, Vol. 48, pp. 266-291.

Moreau, P. and Herd, K.B. (2010), "To each his own? How comparisons with others influence consumers' evaluations of their self-designed products”, Journal of Consumer Research, Vol. 36 No. 5, pp. 806-819.

Morosan, C. and Defranco, A. (2016), "Co-creating value in hotels using mobile devices: a conceptual model with empirical validation", International Journal of Hospitality Management, Vol. 52 No. 1, pp. 131-142.

Neuhofer, B., Buhalis, D. and Ladkin, A. (2012), "Conceptualising technology enhanced destination experiences", Journal of Destination Marketing \& Management, Vol. 1, pp. 36-46.

Neuhofer, B., Buhalis, D. and Ladkin, A. (2015), "Smart technologies for personalized experiences: a case study in the hospitality domain", Electronic Markets, Vol. 25 No. 3, pp. 243-254.

Ngo, V. (2015), "Transportation network companies and the ride sourcing industry: a review of impacts and emerging regulatory frame", City of Vancouver, Vol. 10, pp. 1-100.

OECD (2016), "Policies for the tourism sharing economy", available at: www.oecd-ilibrary.org/industryand-services/oecd-tourism-trends-and-policies-2016/policies-for-the-tourism-sharing-economy_tour-20167-en (accessed 6 March 2019).

Pesonen, A. (2013), "Information and communications technology and market segmentation in tourism: a review", Tourism Review, Vol. 68 No. 2, pp. 14-30. 
Pettigrew, S.F., (2000), "Ethnography and grounded theory: a happy marriage?", Advances in Consumer Research, Vol. 2, pp. 256-260.

Prior, D.D. and Marcos-Cuevas, J. (2016), "Value co-destruction in interfirm relationships: the impact of actor engagement styles", Marketing Theory, Vol. 16 No. 4, pp. 533-552.

Plé, L. (2017), "Why do we need research on value co-destruction?", Journal of Creating Value, Vol. 3 No. 2, pp. 162-169.

Plé, L. and Cáceres, R.C. (2010), "Not always co-creation: introducing interactional codestruction of value in service-dominant logic", Journal of Services Marketing, Vol. 24 No. 6, pp. 430-437.

Quach, S. and Thaichon, P. (2017), "From connoisseur luxury to mass luxury: value co-creation and codestruction in the online environment", Journal of Business Research, Vol. 81, pp. 163-172.

Randall, G. (1997), Do Your Own Market Research, Kogan Page, London, New York, NY.

Ravald, A. and Grönroos, C. (1996), "The value concept and relationship marketing", European Journal of Marketing, Vol. 30 No. 2, pp. 19-30.

Rayle, L., Dai, D., Chan, N., Cervero, R. and Shaheen, S.A. (2016), "Just a better taxi? A survey-based comparison of taxis, transit, and ridesourcing services in San Francisco", Transport Policy, Vol. 45, pp. 168-178.

Rodie, A.R. and Kleine, S. (2000), "Customer participation in services production and delivery", in Swartz, T. and lacobucci, D. (Eds), Handbook of Services Marketing \& Management, Sage, Thousand Oaks, pp. 111-127.

Roggeveen, A.L., Tsiros, M. and Grewal, D. (2012), "Understanding the co-creation effect: when does collaborating with customers provide a lift to service recovery?", Journal of the Academy of Marketing Science, Vol. 40 No. 6, pp. 771-790.

Schneider, B., Young, S.A. and Macey, W.H. (2007), "Service smarts", Marketing Management, Vol. 16, pp. 29-34.

Schoefer, K. and Ennew, C. (2005), "The impact of perceived justice on consumers' emotional responses to service complaint experiences", The Journal of Services Marketing, Vol. 19 No. 5, pp. 261-270.

Skourtis, G., Décaudin, J.M. and loannis, A. (2016), “"Service failures as value Co-destruction moments”, in Obal M., Krey N. and Bushardt C. (Eds), Let's Get Engaged! Crossing the Threshold of Marketing's Engagement Era, Developments in Marketing Science: Proceedings of the Academy of Marketing Science, Springer, Cham, p. 565.

Smaliukiene, R., Chi-Shiun, L. and Sizovaite, I. (2015), "Consumer value co-creation in online business: the case of global travel services", Journal of Business Economics and Management, Vol. 16 No. 2, pp. 325-339

Smith, A. (2013), "The value co-destruction process: a customer resource perspective", European Journal of Marketing, Vol. 47 Nos 11/12, pp. 1889-1909.

Sthapit, E. (2018a), "My bad for wanting to try something unique: sources of value co-destruction in the airbnb context", Current Issues in Tourism, Vol. 35.

Sthapit, E. (2018b), "Exploring the antecedents of value no-creation: cruise tourists' perspective", Anatolia, Vol. 29 No. 4, pp. 617-619.

Sthapit, E. and Björk, P. (2018), "Towards a better understanding of interactive value formation: three value outcomes perspective", Current Issues in Tourism, Vol. 26.

Sthapit, E. and Jiménez-Barreto, J. (2018a), "Sharing in the host-guest relationship: perspectives on the airbnb hospitality experience", Anatolia, Vol. 29 No. 2.

Sthapit, E. and Jiménez-Barreto, J. (2018b), "You never know what you will get in an airbnb: poor communication destroys value for guests", Current Issues in Tourism, Vol. 1.

Stieler, M., Weismann, F. and Germelmann, C.C. (2014), "Co-destruction of value by spectators: the case of silent protests”, European Sport Management Quarterly, Vol. 14 No. 1, pp. $72-86$.

Strauss, A. and Corbin, J. (1990), Basics of Qualitative Research: Grounded Theory Procedures and Techniques, Sage Publications, Newbury Park.

Sugathan, P., Ranjan, K.R. and Mulky, A.G. (2017), "An examination of the emotions that follow a failure of co-creation", Journal of Business Research, Vol. 78, pp. 43-52. 
Sundararajan, A. (2016), The Sharing Economy: The End of Employment and the Rise of Crowdbased Capitalism, MIT Press, Cambridge.

The Guardian (2018), "Woman raped by uber driver in India sues company for privacy breaches", available at: www.theguardian.com/technology/2017/jun/15/uber-india-woman-rape-lawsuit (accessed 5 January 2018).

Torres, E.N., Wei, W. and Hua, N. (2017), "Towards understanding the effects of time and emotions on the vacation experience", Tourism Review, Vol. 72 No. 4, pp. 357-374.

Tussyadiah, I.P. and Wang, D. (2016), "Tourists attitudes toward proactive smartphone systems", Journal of Travel Research, Vol. 55 No. 4, pp. 493-508.

Vaerenbergh, Y.V. and Orsingher, C. (2016), "Service recovery: an integrative framework and research agenda", Academy of Management Perspectives, Vol. 30 No. 3, pp. 328-346.

Vafeas, M., Hughes, T. and Hilton, T. (2016), "Antecedents to value diminution”, Marketing Theory, Vol. 16 No. 4, pp. 469-491.

Vargo, S.L. and Lusch, R.F. (2008), "Service-dominant logic: continuing the evolution", Journal of the Academy of Marketing Science, Vol. 36 No. 1, pp. 1-10.

Vargo, S.L., Maglio, P.P. and Akaka, M.A. (2008), "On value and value co-creation: a service systems and service logic perspective”, European Management Journal, Vol. 26 No. 3, pp. 145-152.

Wang, M. and Mu, L. (2018), "Spatial disparities of uber accessibility: an exploratory analysis in Atlanta, USA", Computers, Environment and Urban Systems, Vol. 67, pp. 169-175.

Wieland, H., Polese, F., Vargo, S. and Lusch, R. (2012), "Toward a service (eco) systems perspective on value creation", International Journal of Service Science, Management, Engineering, and Technology, Vol. 3 No. 3 , pp. 12-24.

Wu, M.Y. and Pearce, P.L. (2014), "Appraising netnography: towards insights about new markets in the digital tourist era", Current Issues in Tourism, Vol. 17 No. 5, pp. 463-474.

Yi, S. and Baumgartner, H. (2004), "Coping with negative emotions in purchase-related situations", Journal of Consumer Psychology, Vol. 14 No. 3, pp. 303-317.

Yin, J., Qian, L. and Shjen, J. (2018), "From value co-creation to value co-destruction? the case of dockless bike sharing in China", Transportation Research Part D, Vol. 71.

Zeithaml, V.A. (1988), "Consumer perceptions of price, quality, and value: a means-end model and synthesis of evidence", Journal of Marketing, Vol. 52 No. 3, pp. 2-22.

Zhang, T., Lu, C., Torres, E. and Chen, P.-J. (2018), "Engaging customers in value co-creation or codestruction online", Journal of Services Marketing, Vol. 32 No. 1, pp. 57-69.

Zhu, G., So, K.K.F. and Hudson, S. (2017), "Inside the sharing economy: understanding consumer motivations behind the adoption of mobile applications", International Journal of Contemporary Hospitality Management, Vol. 29 No. 9, pp. 2218-2239.

\section{Further reading}

Vargo, S.L. and Lusch, R.F. (2004), "Evolving to a new dominant logic for marketing", Journal of Marketing, Vol. 68 No. 1, pp. 1-17.

\section{Corresponding author}

Erose Sthapit can be contacted at: erose_sthapit@hotmail.com

For instructions on how to order reprints of this article, please visit our website: www.emeraldgrouppublishing.com/licensing/reprints.htm

Or contact us for further details: permissions@emeraldinsight.com 